\title{
A Note on Orthography, Transcription, and Vocabulary
}

Anakalangese (na bilu Anakalang) is a distinct dialect within the cluster of (more or less) mutually intelligible language varieties of eastern Sumba. There is a great deal of microregional and possibly generational variation within Anakalangese. The language of Parewatana is further distinguished from Anakalangese by the preference for certain lexical items and some phonological variants. These do not, however, interfere with communication: I have even seen a spokesman from Parewatana using his own dialect to serve one group of Anakalangese in addressing another. Anakalangese is rarely written and there is no standardized orthography, nor has it received linguistic analysis except for some brief comments (Onvlee [1936] 1973c) and lexical cross-references (Onvlee 1984). In my transcriptions I make no effort to standardize across the dialectal and idiolectal variations I recorded, although I do defer to those few personal names that have acquired an accepted written form (e.g., Umbu Sappy Pateduk instead of Ubu Sàpi Pateduk). The subscript (.) marks implosive consonants. A useful weighing of the pros and cons of Sumbanese orthography, with particular reference to the west Sumbanese language of Weyewa, is given by Joel C. Kuipers (1990: xviiixxiii), and I concur with him in most respects. I differ slightly, however, in my treatment of vowels, in which I follow the east Sumbanese transcriptions of Lois Onvlee and Oe. Kapita. Kuipers doubles consonants except when this would result in doubled digraphs (e.g., /ngng/), in which case he accents the preceding vowel. In the interest of treating vowels consistently while also avoiding doubled digraphs, I retain the 
accent across the board. (Kuipers rightly refers to indigenous writing habits in making his choice; in Anakalang, however, I have already been obliged to deviate from local writing since, as far as I know, it never indicates the phonemic distinction between implosive and other consonants.) For most Anakalangese, $/ \mathrm{h} / \mathrm{and} / \mathrm{s} /$ are not phonemically distinct and may co-occur in the speech of a single speaker.

\section{CONSONANTS}

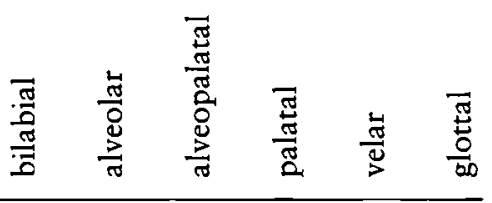

\begin{tabular}{lcccccc}
\hline stop & & & & & & \\
$\quad$ voiced & b & d & & & $g$ & \\
$\quad$ v. impl. & b & & d & & & \\
$\quad$ voiceless & p & t & & & $\mathrm{k}$ & \\
fricative & & s & j & & & h \\
nasal & m & n & & & ng & \\
lateral & & l & r & & & \\
semivowel & w & & & $y$ & & \\
\hline
\end{tabular}

For the vowels (a, e, i, o, u) and diphthongs (au, ai) see discussions in Kuipers (1990) and Onvlee ([1936] 1973c). Canonical stress is on the penultimate syllable of the root, unaffected by affixation. The abbreviation "Indo." indicates words and expressions in Indonesian and the local variants of Malay.

Anakalangese pronouns do not indicate gender. The first-person plural does indicate whether the addressee is included or excluded, which I note where relevant.

In transcribing ritual speech my chief concern has been to keep the poetic units visible, sometimes at the expense of intonation and breath groups (for the issues raised by transcription choices, see Hymes [1977] 1981, Ochs 1979). The three principal units that I indicate are the line, the couplet, and the stanza (for further discussion of these units, in Weyewa, a west Sumbanese language, see Kuipers 1990, although my definition of stanza is narrower than his). By stanza, I mean a set of intercalated couplets, the two lines of each couplet being separated by at 
least one line of another couplet. In these cases, couplets are indicated by indentation: the components of the first couplet are flush left, the next couplet indented one step, those of the third couplet two steps, and so forth. Unpaired phrases, such as "and another thing" (bigulna), receive their own line, and back-channel cues are placed in parentheses. Throughout the text, double quotation marks enclose verbatim reported speech, mostly from tape recordings, and single quotation marks indicate statements for which I can offer a close report (from notes taken at the time or shortly thereafter) but cannot vouch for word-for-word accuracy.

In the interests of making the book accessible to the nonspecialist, I have limited the use of Anakalangese vocabulary. This poses, of course, real ethnographic problems, tempting both author and reader to accept a closer semantic correspondence between Anakalangese and English than is warranted. I have retained a few terms whose importance and problematic translatability I wish to underscore. These, and the places where they are most fully discussed, are:

\begin{tabular}{|c|c|}
\hline dewa & soul, spirit, fate, fortune (chap. 8 ) \\
\hline desa & $\begin{array}{l}\text { Indonesian administrative unit at the "village" } \\
\text { level }\end{array}$ \\
\hline horung & formal negotiation between affines (chap. 6) \\
\hline kaḅisu & clan (chap. 2) \\
\hline kajiàla & ritual speech of negotiation (chap. 4) \\
\hline mamuli & omega-shaped metal valuable (chap. 3 ) \\
\hline ngàba wini & affines of the husband's side \\
\hline pata & $\begin{array}{l}\text { patterned way of doing things; ancestral custom } \\
\text { (chap. } 7 \text { ) }\end{array}$ \\
\hline Rabu (Rambu) & $\begin{array}{l}\text { honorific term of address and reference for } \\
\text { women }\end{array}$ \\
\hline ratu & priest, ritual specialist \\
\hline bu (Umbu) & honorific term of address and reference for men \\
\hline inang & ritual spokesman and negotiator (chap. 6) \\
\hline & affines of the wife's side \\
\hline
\end{tabular}


